\title{
Impact of Lake-Level and Climate Changes on Microbial Communities in a Terrestrial Permafrost Sequence of the El'gygytgyn Crater, Far East Russian Arctic
}

\author{
Juliane Bischoff, ${ }^{1,2 \dagger}$ Kai Mangelsdorf, ${ }^{2}$ Georg Schwamborn ${ }^{1}$ and Dirk Wagner ${ }^{3 *}$ \\ 1 Alfred Wegener Institute, Helmholtz Centre for Polar and Marine Research, Research Unit Potsdam, Potsdam, Germany \\ 2 GFZ German Research Centre for Geosciences, Section 4.3 Organic Geochemistry, Telegrafenberg, Potsdam, Germany \\ ${ }^{3}$ GFZ German Research Centre for Geosciences, Section 4.5 Geomicrobiology, Telegrafenberg, Potsdam, Germany
}

\begin{abstract}
Microbial permafrost communities play an important role in carbon cycling and greenhouse gas fluxes. Despite the importance of these processes, there is a lack of knowledge about how environmental and climatic changes affect the abundance and composition of microorganisms. Here, we investigated the changing distribution of permafrost microorganisms in response to climate and lake-level changes. The permafrost core was drilled at the near shore of Lake El'gygytgyn, Far East Russian Arctic, and a combined microbiological and lipid biomarker approach was applied. The lower part of the permafrost core, deposited under subaquatic conditions, contains only small amounts of microbial signals; total organic carbon (TOC) content is sparse. After exposure of the site to subaerial conditions during the Allerød, the abundance of Bacteria and Archaea started to increase and the lake-level change is especially evidenced by the relative proportion of archaeal biomarkers. This increase is supported by rising bacterial and archaeal $16 \mathrm{~S}$ ribosomal ribonucleic acid (rRNA) gene copy numbers and significant amounts of TOC during the late Allerød. After a small decrease during the colder Younger Dryas, the TOC content and the microbial signals strongly increase during the Holocene, presumably stimulated by pedogenesis. The occurrence of intact phospholipids indicates the presence of living microorganisms in these deposits. Our data suggest that methane formation is mainly expected for the subaerial interval, especially the Holocene where methanogens were identified by fingerprinting. This study emphasises the role of the uppermost permafrost deposits as a hotspot of carbon cycling in arctic environments, especially in the light of expected future global warming. Copyright @ 2014 John Wiley \& Sons, Ltd.
\end{abstract}

KEY WORDS: microorganism; microbial succession; lipid biomarkers; permafrost

\section{INTRODUCTION}

Lake El'gygytgyn, a meteor impact crater formed about 3.6 million years ago, is located in the permafrost region of the Far East Russian Arctic. The frozen ground in the permafrost flat surrounding the lake represents an extreme habitat for microbial life. The mean annual air temperature of $-10.3^{\circ} \mathrm{C}$ is quite low (Nolan and Brigham-Grette, 2007), the slope deposits around the lake largely consist of sand and gravel, and there is little carbon available in the catchment (Schwamborn et al., 2012). Microbiological studies on Lake El'gygytgyn sediments have up to now focused only

*Correspondence to: D. Wagner, GFZ German Research Centre for Geosciences, Section 4.5 Geomicrobiology, C 425, Telegrafenberg, 14473 Potsdam, Germany. E-mail: Dirk.Wagner@gfz-potsdam.de ${ }^{\dagger}$ Present address: School of Civil Engineering and Geosciences, Newcastle University, Newcastle upon Tyne, UK on lake deposits from the centre of the lake (site 5011-1, Figure 1b). Significant amounts of bacterial and archaeal genes and lipid biomarkers were found in the lake deposits (J. Bischoff et al., manuscript in preparation). Analysing a Middle Pleistocene time interval, this investigation shows that the microbial communities within the lake respond to glacialinterglacial climate variations. Higher numbers of microorganisms occurred during the interglacials, presumably related to an increased carbon availability in the lake (J. Bischoff et al., manuscript in preparation). The present study focuses on microbiological investigations on the terrestrial permafrost surrounding Lake El'gygytgyn, which is representative of the lake catchment area.

As Lake El'gygytgyn formed, its western shore was exposed to significant environmental and climatic changes. During the Middle and Late Pleistocene, the lake levels were higher than today and the modern permafrost margin was inundated several times (Juschus et al., 2011; Schwamborn 
J. Bischoff et al.
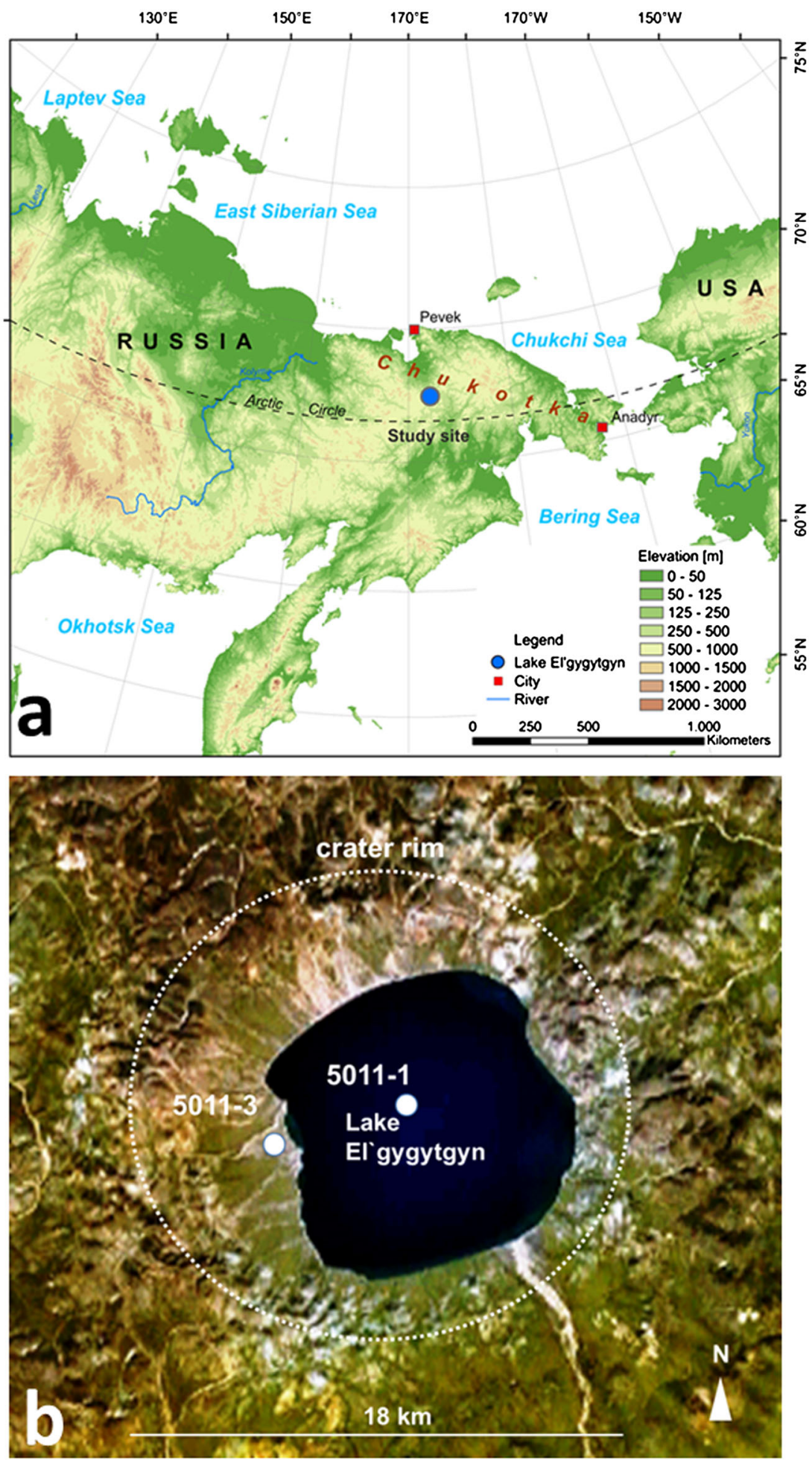

Figure 1 (a) Location of Lake El'gygytgyn in far eastern Russia. (b) Landsat image showing Lake El'gygytgyn and the drilling site 5011-3 on the western shore of the lake. Site 5011-1 marks the drilling site that recovered sediments from the centre of the lake. Figure modified after Schwamborn et al. (2012). This figure is available in colour online at wileyonlinelibrary.com/journal/ppp 
et al., 2012). The lake marginal permafrost thawed because of talik inception below the lake water column, and sandy flooding horizons alternated with gravelly layers deposited on the slope (Schwamborn et al., 2012). The last lake-level highstand that flooded the study site (5011-3, Figure 1b) took place during the Allerød, before the shoreline receded during the late Allerød (Schwamborn et al., 2012). Exposed to the atmosphere, the talik area froze over and subaerial alluvial deposits, prograding from the slope, buried the lake deposits in the near-shore area (Mottaghy et al., 2013). Exposed lake shore areas, which currently experience subaerial conditions, can be found mainly north and west of the lake (Figure 1b).

This study uses a combined approach of microbial lipid biomarkers and gene analyses in order to investigate how the abundance and composition of the microbial communities vary with climatic and environmental changes in the lake shore area. Glycerol dialkyl glycerol tetraethers (GDGTs), characteristic biomarkers for Bacteria and Archaea (Weijers et al., 2006), can be considered as fossil markers, because they are already partly degraded due to loss of the headgroups and they are relatively stable outside intact cells (Pease et al., 1998). Studies in Siberian permafrost (Bischoff et al., 2013) and Lake El'gygytgyn sediments (J. Bischoff et al., manuscript in preparation) have shown that GDGTs and gene analyses are suitable approaches to reconstruct the changes in Arctic microbial communities that have occurred in response to climate variabilities in sediments $\leq 480 \mathrm{ka}$. Thus, by combining biogeochemical and molecular biological methods, this study aims to assess the impact of lake-level and climate changes on microbial communities with a specific focus on methane-producing Archaea (methanogens) in the lake shore area during the Late Pleistocene and Holocene, and to characterise extremophile microorganisms in the near-shore permafrost of Lake El'gygytgyn.

\section{MATERIALS AND METHODS}

\section{Study Site}

Lake El'gygytgyn $\left(67^{\circ} 27^{\prime} \mathrm{N}, 172^{\circ} 05^{\prime} \mathrm{E}\right)$ is located $492 \mathrm{~m}$ asl in an impact crater in the Chukotka-Anadyr mountain belt, northeastern Russia (Figure 1a). A meteorite impact 3.6 million years ago (Layer, 2000) excavated a crater about $18 \mathrm{~km}$ in diameter that is partially filled with an off-centred lake $12 \mathrm{~km}$ in diameter (Figure 1b). Data from an automated meteorological station installed at the southern lake shore near the outflow river in 2000 (Nolan and Brigham-Grette, 2007; Nolan, 2012) show that over the period from 2001 to 2009 the average air temperature was $-10.3^{\circ} \mathrm{C}$ with extremes from $-40{ }^{\circ} \mathrm{C}$ to $28^{\circ} \mathrm{C}$. The mean annual liquid precipitation from 2002 to 2007 was $126 \mathrm{~mm}$ with extremes from $70 \mathrm{~mm}$ in 2002 to $200 \mathrm{~mm}$ in 2006 (Nolan, 2012). The site is located in the zone of continuous permafrost and the permafrost is estimated to reach a thickness of up to $350 \mathrm{~m}$ (Mottaghy et al., 2013). There is no permafrost below the lake. In 2003, the active layer surrounding the lake was reported to be $0.4 \mathrm{~m}$ thick for peaty silts and $0.5-0.8 \mathrm{~m}$ thick for sandand gravel-rich deposits (Schwamborn et al., 2012). The lower part of the core $(20.0-8.5 \mathrm{~m})$ was deposited under subaquatic conditions as indicated by hydrochemical changes of the ground ice (Schwamborn et al., 2012). According to an age estimate based on pollen data (Andreev et al., 2012), a sandy bed at the bottom of the core (c. 20-19 m depth) was likely formed during the interglacial Marine Isotope Stage (MIS) 7. No pollen was available from 19 to $9.5 \mathrm{~m}$ depth, preventing an age assessment of these deposits. From terrace remnants partly found around the lake and which are $10 \mathrm{~m}$ higher than the modern lake level, a relative lake-level highstand is interpreted for MIS 5 (Glushkova and Smirnov, 2007). In our core, distinct lake sediments from that time are presumably eroded by slope processes, whose deposits overlie the site (Schwamborn et al., 2012). The 9.5 to $2.5 \mathrm{~m}$ depth interval was assigned to the Allerød because of its pollen assemblage (Andreev et al., 2012). The sandy bed between 9.6 and $9.1 \mathrm{~m}$ depth is interpreted as a flooding horizon from a lake-level highstand in the Allerød (Schwamborn et al., 2012). After this highstand, the lake level decreased and the upper part of the core (8.5 to $0 \mathrm{~m}$ ), assigned to the later Allerød, Younger Dryas and the Holocene, was deposited under subaerial conditions (Schwamborn et al., 2012).

\section{Drilling and Sample Material}

From November to December 2008, the El'gygytgyn Drilling Project was conducted within the scope of the International Scientific Continental Drilling Program (ICDP; http:// www.icdp-online.org). A $141.5 \mathrm{~m}$ long core (5011-3, Figure 1b) of fully frozen deposits was drilled on the western shore of the lake $\left(76^{\circ} 29.1^{\prime} \mathrm{N}, 171^{\circ} 56.7^{\prime} \mathrm{E}\right)$ at $500 \mathrm{~m}$ asl and $350 \mathrm{~m}$ away from the modern lake shore. Further information on the drilling is given by Melles et al. (2011, 2012) and Schwamborn et al. (2012).

During shipping and storage, the core segments remained frozen. The frozen core segments were transferred to the laboratory and cleaned, and then described in detail. Sampling of the uppermost $20 \mathrm{~m}$ of the core used in this study was conducted in a climate-controlled laboratory at $-12^{\circ} \mathrm{C}$. Samples were taken on average every $0.5 \mathrm{~m}$, or where sediment changes occurred. The core diameter was $11 \mathrm{~cm}$ and the sampled sections were 15 to $20 \mathrm{~cm}$ long. The gross weight of each sample was 2 to $3 \mathrm{~kg}$. Subsamples weighing about $90 \mathrm{~g}$ were taken from the undisturbed inner parts of these sections. Samples for biomarker analyses were stored in combusted brown glass jars. Samples for microbial analyses were put in sterile $2 \mathrm{~mL}$ tubes and kept frozen at $-20^{\circ} \mathrm{C}$ for subsequent analyses. All reported core depths are the mean field depths of the homogenised sample core section.

\section{Sediment Properties}

Total organic carbon (TOC) was measured with a Vario EL III element analyser (Elementar Analysensysteme, Hanau, Germany) using freeze-dried and homogenised 
samples $(5 \mathrm{mg})$ that had been treated with $\mathrm{HCl}(10 \%)$ at a temperature of $80^{\circ} \mathrm{C}$ to remove carbonate. For further details, see Schwamborn et al. (2012).

\section{Lipid Biomarker Analysis}

Freeze-dried and ground samples were extracted using a modified Bligh and Dyer (1959) extraction. For phospholipid quantification, internal phospholipid standards (1-palmitoyl (D31)-2-hydroxy-glycero-3-phosphatidylcholine and 1, 2distearoyl(D70)-glycero-3-phosphatidylcholine) were added. The obtained sediment extract was separated into fractions of different polarity (low polar lipids, free fatty acids, glycolipids and phospholipids). For details on the sample preparation method, see Zink and Mangelsdorf (2004).

\section{Detection of GDGTs and Archaeol}

Tetraether lipids and archaeol in the 'low polar lipids' fraction were analysed using a high-performance liquid chromatography-atmospheric pressure chemical ionisation mass spectrometry method described in Schouten et al. (2007). Blanks (pre-heated sea sand) were measured regularly and did not contain any GDGTs or archaeol. For details on the applied method, see Bischoff et al. (2013).

\section{Detection of Phospholipid Fatty Acids (PLFAs)}

One-third of the phospholipid fraction was used for alkaline hydrolysis to obtain the methylated PLFAs by following the method described by Müller et al. (1990). The trans-esterified (methylated) PLFAs were directly analysed on a gas chromatographic system (Trace GC Ultra, Thermo Fisher Scientific Inc., Waltham, Massachusetts, USA) coupled with a mass spectrometer (DSQ, Thermo Fisher Scientific Inc., Waltham, Massachusetts, USA). For details on the instrument parameters, see Vetter et al. (2011). Blanks did not contain any PLFAs.

\section{Deoxyribonucleic Acid (DNA) Extraction and Amplification}

The total genomic DNA was extracted in duplicate $0.75 \mathrm{~g}$ samples of terrestrial permafrost deposits using a Power Soil ${ }^{\mathrm{TM}}$ DNA Isolation Kit (Mo Bio Laboratories Inc., Carlsbad, California, USA), according to the manufacturer's protocol with the addition of a beat-beating step to improve the mechanical efficiency of DNA extraction. The methanogenic bacterial small subunit (SSU) ribosomal ribonucleic acid (rRNA) genes were amplified in a nested polymerase chain reaction (PCR) approach using the primer pair ArUn4F and 958 R (DeLong, 1992; Hershberger et al., 1996), followed by a subsequent amplification using GC_0357Fa and $0691 \mathrm{R}$ (Watanabe et al., 2004) following the protocol used in Bischoff et al. (2013). The denaturing gradient gel electrophoresis (DGGE) analyses were conducted as described previously by Ganzert et al. (2007) and selected bands were cut from the gel. After re-amplification, the DNA amplicons were sequenced by GATC Biotech AG (Konstanz, Germany).

\section{Quantitative PCR Analysis of Archaeal and Bacterial SSU rRNA Genes}

The SSU rRNA gene copy numbers of Bacteria and Archaea in terrestrial permafrost deposits were determined using a real-time PCR approach. The primer pairs Uni $331 \mathrm{~F} / 797 \mathrm{R}$ (Nadkarni et al., 2002) and A $571 \mathrm{~F} / \mathrm{UA}$ 1406R (Baker et al., 2003) were used to amplify fragments of $466 \mathrm{bp}$ and $687 \mathrm{bp}$ length from the bacterial and archaeal SSU rRNA genes, respectively. Real-time PCR reactions were conducted in analytical triplicates in a Rotor Gene Q (Quiagen, Hilden, Germany) instrument using the RotorGene SYBR Green PCR Kit (Quiagen) and $0.5 \mathrm{mM}$ of each primer. As a template, $3 \mu$ l of purified and diluted DNA extract (1:10) was added. Cycling conditions were as follows: initial denaturation at $95^{\circ} \mathrm{C}$ for $10 \mathrm{~min}, 40-50$ cycles of denaturation at $95^{\circ} \mathrm{C}$ for $20 \mathrm{~s}$, annealing at $57^{\circ} \mathrm{C}$ respectively for $20 \mathrm{~s}$, and elongation at $72^{\circ} \mathrm{C}$ for $45-90 \mathrm{~s}$. A standard curve was generated using known dilutions $\left(10^{1}-10^{7}\right.$ gene copies) of the target fragments amplified from Bacillus subtilis (for Bacteria) and Methanosarcina vacuolata (for Archaea). After each run, melting curve analyses were performed to ensure correct amplification of the target sequence.

\section{Phylogenetic Analysis}

The obtained sequence data were checked for quality and length using Sequencher® software (Version 4.7., Gene Codes Inc., Ann Arbor, Michigan, USA); when indicated, sequences were cut or edited. The sequences were aligned with full-length sequences of a sufficient quality provided by the Silva rRNA database project using the online available alignment software (http://www.arb-silva.de; Pruesse et al., 2007). The phylogenetic analysis of partial 16S rRNA gene sequences was performed using the ARB software package (http://www.arb-home.de; Ludwig et al., 2004). The phylogenetic tree (maximum likelihood) was constructed using the 'pos_var_ssu:ref:archaea' and 'termini' filters provided by ARB. For a better overview, only selected data are shown in the resulting tree.

\section{RESULTS \\ TOC Content}

Overall, the TOC content varied between $<0.1$ and $1.7 \mathrm{wt}$ per cent throughout the studied core section (Figure 2a). The uppermost $1.25-0 \mathrm{~m}$ could be clearly distinguished from the rest of the core by distinctly higher TOC contents ranging between 0.4 and $1.7 \mathrm{wt}$ per cent. Further downcore, the organic carbon content decreased and was below the analytical detection limit of $0.1 \mathrm{wt}$ per cent below $4 \mathrm{~m}$ core depth. 


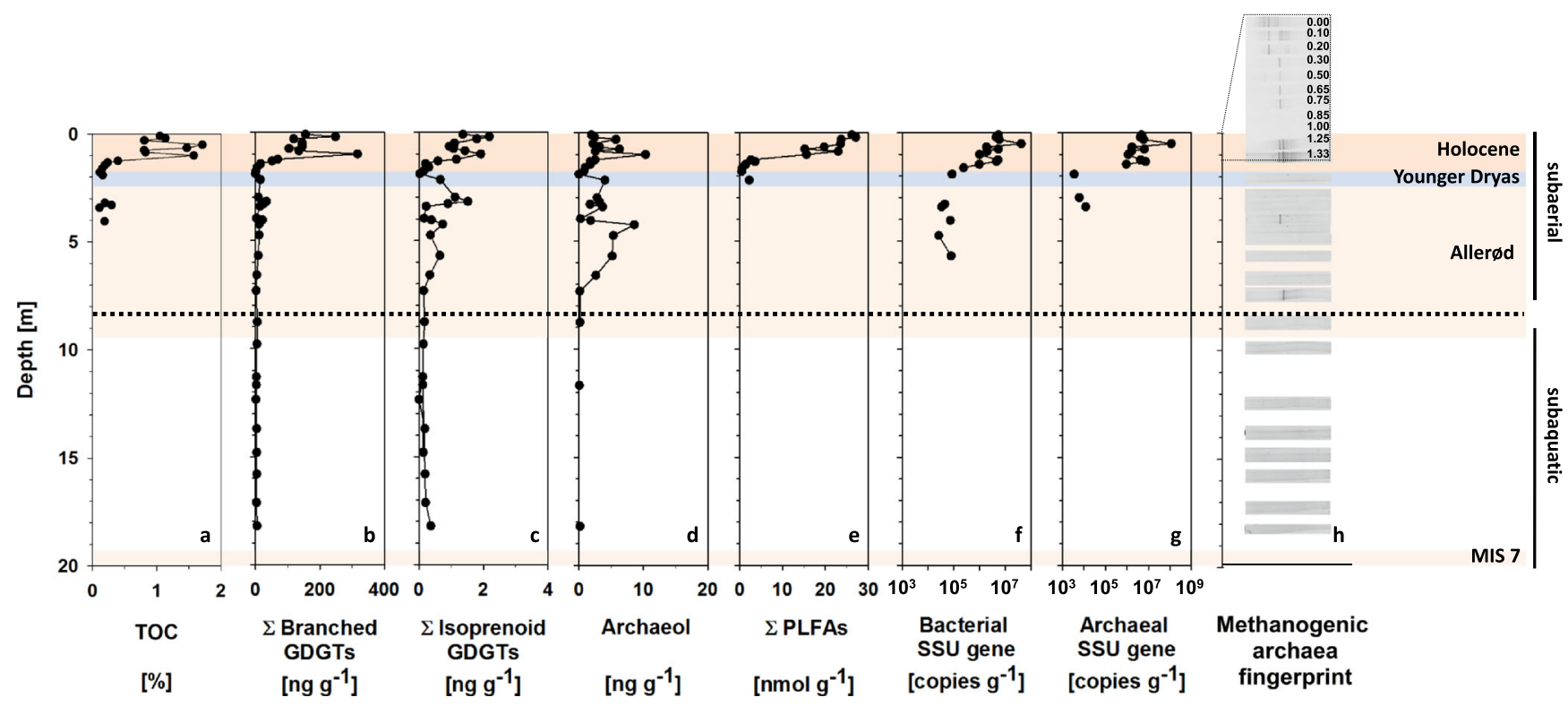

Figure 2 Vertical profiles of El'gygytgyn terrestrial permafrost sequences comprising deposits of Marine Isotope Stage 7 (MIS 7 ) to the Holocene,

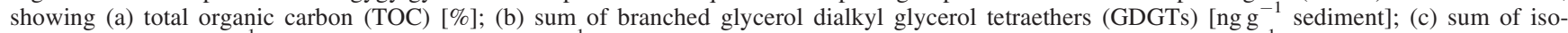
prenoid GDGTs [ng g ${ }^{-1}$ sediment]; (d) archaeol [ng g ${ }^{-1}$ sediment]; (e) sum of phospholipid fatty acids (PLFAs) [nmol g ${ }^{-1}$ sediment]; (f) abundance of bacterial small subunit ribonucleic acid (SSU RNA) genes [copies $\mathrm{g}^{-1}$ sediment]; (g) abundance of archaeal SSU RNA genes [copies $\mathrm{g}^{-1}$ sediment]; (h) methanogenic fingerprints. The underlining palaeoclimate reconstruction is based on Andreev et al. (2012) and the lake-level reconstruction is according to Schwamborn et al. (2012).

\section{Distribution of Lipid Biomarkers}

GDGTs were detected throughout the entire upper $20 \mathrm{~m}$ of the El'gygytgyn terrestrial permafrost sequence (Figure 2b-d). Branched GDGTs, characteristic markers for Bacteria (Weijers et al., 2006), were predominantly found in the uppermost $1.25-0 \mathrm{~m}$ of the deposits, with concentrations of up to $316 \mathrm{ng} \mathrm{g}^{-1}$ sediment dry weight (dw) (Figure $2 \mathrm{~b}$ ). Throughout the remaining core, the amount of total branched GDGTs decreased below $10 \mathrm{ng} \mathrm{g}^{-1}$ sediment dw. Isoprenoid GDGTs, characteristic markers for Archaea (Weijers et al., 2006), were less abundant; total amounts ranged from 0 to $2 \mathrm{ng} \mathrm{g}^{-1}$ sediment $d w$ throughout the core (Figure 2c). Highest values were observed in the uppermost layers $(1.25-0 \mathrm{~m})$, but also in an interval between 3.4 and $3 \mathrm{~m}$ depth with up to $1.5 \mathrm{ng} \mathrm{g}^{-1}$ sediment dw. Below $7.3 \mathrm{~m}$, the concentration of isoprenoid GDGTs decreased to values of $0.1 \mathrm{ng} \mathrm{g}^{-1}$ sediment dw. Archaeol, a characteristic marker for methanogenic Archaea (Pancost et al., 2011), was abundant throughout the uppermost $7 \mathrm{~m}$ of the analysed sediments, with concentrations ranging from 0.1 to $10 \mathrm{ng} \mathrm{g}^{-1}$ sediment $\mathrm{dw}$ (Figure 2d). The highest amounts of archaeol were detected in intervals from 6.6-4.25 and $1-0.3 \mathrm{~m}$ depths. Total amounts of PLFAs, markers for living Bacteria because they rapidly decay after cell death (White et al., 1979), were highest in the uppermost $1.25 \mathrm{~m}$ of the permafrost sequence with up to $27 \mathrm{nmol} \mathrm{g}^{-1}$ sediment $\mathrm{dw}$ (Figure 2e). Below $3 \mathrm{~m}$ depth, the amounts of total PLFA were below the detection limit.

\section{Composition of Archaeol and Isoprenoid GDGTs}

Both archaeol and isoprenoid GDGTs increase between $7.3 \mathrm{~m}$ depth and the core top, although by differing amounts. Their relative proportion is shown in Figure 3. Sediments from 20 to $8.5 \mathrm{~m}$ depth were characterised by a high relative proportion of GDGT-0 (no pentacyclic ring, $\mathrm{m} / \mathrm{z}=1302$ ); GDGT-0 accounted for about 50 per cent of all detected isoprenoid GDGTs. Additionally, a high proportion of crenarchaeol $(\mathrm{m} / \mathrm{z}=1292)$ was found in the same sediment interval, 25 per cent on average. In contrast, archaeol was almost undetectable, except at depths of 18.2, 11.7 and $8.8 \mathrm{~m}$. The composition of isoprenoid GDGTs in the sediment interval from 8.5 to $0 \mathrm{~m}$ depth was characterised by an increase in the relative proportion of archaeol, which accounted for on average 80 per cent of the total isoprenoid GDGTs, whereas the proportions of crenarchaeol and GDGT-0 decreased to below 10 per cent. The presence of GDGT-2 (two pentacyclic rings, $\mathrm{m} / \mathrm{z}=1298$ ) and GDGT-3 (three pentacyclic rings $\mathrm{m} / \mathrm{z}=1296$ ) was limited to the uppermost $8 \mathrm{~m}$ of the core, whereas GDGT-3 was exclusively found in the uppermost layers ( 1.3 to $0 \mathrm{~m}$ depth). GDGT-1 (one pentacyclic ring, $\mathrm{m} / \mathrm{z}=1300$ ) and GDGT-4 (four pentacyclic rings $\mathrm{m} / \mathrm{z}=1294$ ) occurred throughout all analysed samples, but their presence as a proportion of all isoprenoid GDGTs was highest in the uppermost 4 to $0 \mathrm{~m}$ depth (average 5\%) and further downcore in the 18.20 to $13.7 \mathrm{~m}$ depth (average 13\%). 
J. Bischoff et al.

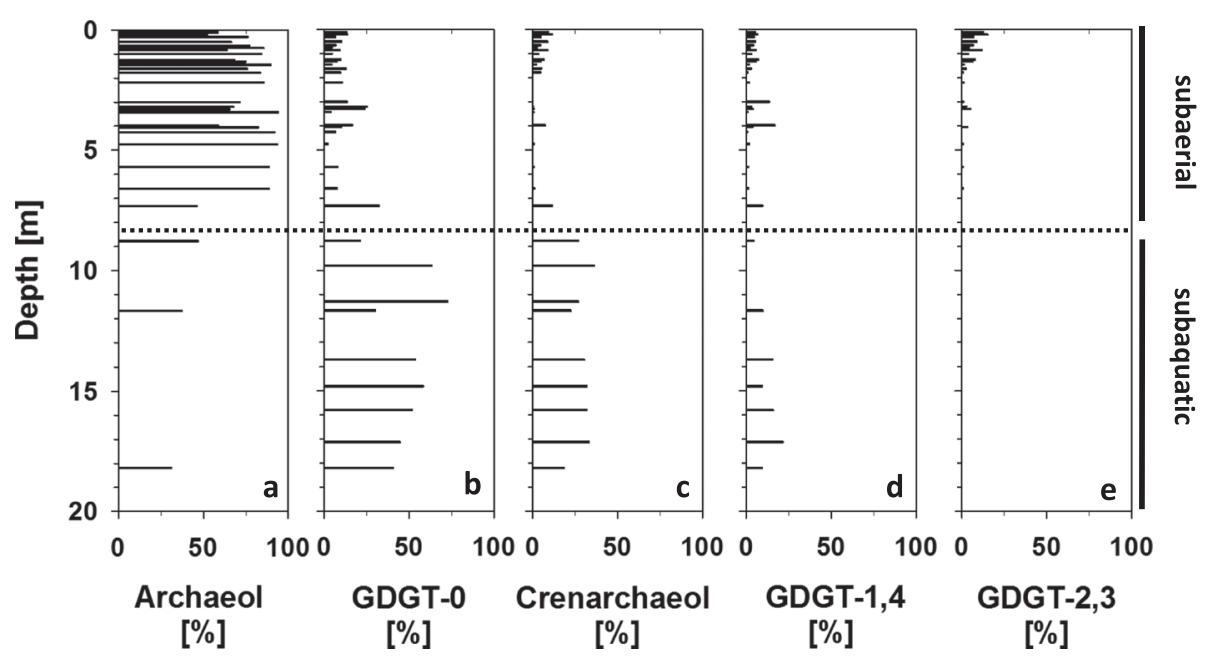

Figure 3 Relative composition of isoprenoid glycerol dialkyl glycerol tetraethers (GDGTs) and archaeol in the shore permafrost deposits of Lake El'gygytgyn with depth. The environmental reconstruction is according to Schwamborn et al. (2012).

\section{Quantification of Bacterial and Archaeal Genes}

Bacterial and archaeal SSU rRNA gene copy numbers (Figure 2f, g) were highest in the uppermost $2 \mathrm{~m}$, with $4.2 \times 10^{7}$ and $1.2 \times 10^{8}$ copies $\mathrm{g}^{-1}$ sediment for bacterial and archaeal genes, respectively. Downcore, these values decreased considerably and no gene copy numbers were calculated for samples below $5.7 \mathrm{~m}$ depth for Bacteria and $3.4 \mathrm{~m}$ depth for Archaea due to the analytical detection limit.

\section{Analysis of Methanogenic Community Fingerprints}

DGGE analyses were conducted to obtain a genetic fingerprint profile of methanogenic Archaea throughout the El'gygytgyn terrestrial permafrost sequence. In total, 45 distinct bands were obtained, indicating microbial community changes with increasing depth (Figure $2 \mathrm{~h}$ ). Overall, the amplification of methanogenic SSU genes was generally limited to the uppermost $1.3 \mathrm{~m}$. Further downcore (from 18.3 to $1.3 \mathrm{~m}$ depth), the abundance of microbial DNA decreased strongly and phylogenetic analyses were essentially not possible. The highest variety of bands was detected in surface layers ( $3-5$ bands, 0.2 to $0 \mathrm{~m}$ depth). From 0.75 to $0.2 \mathrm{~m}$ depth, a lower variety of bands was detected; only one of these bands was distinct. Between 1.0 and $0.85 \mathrm{~m}$ depth, no bands were obtained. In contrast, in the interval between 1.33 and $1.25 \mathrm{~m}$ depth up to five bands were detected. Subsequently, only one distinct band was detected at $7.33 \mathrm{~m}$ depth and another at $3.98 \mathrm{~m}$ depth. No bands occurred below $8 \mathrm{~m}$ depth. In total, eight sequences were excluded from further analyses because of insufficient quality or length of the obtained DNA sequence. Successfully sequenced phylotypes (35 sequences) were classified as members of the phylum Crenarchaeota (7) and Euryarchaeota (28). These were assigned to the class Methanomicrobia, including the orders Methanosarcinales and Methanomicrobiales (Figure 4).

\section{DISCUSSION}

\section{Microbial Communities in Subaquatic Deposits}

The deposits of the study site were influenced by alternating subaerial and subaquatic conditions (Schwamborn et al., 2012). The fundamental change in the depositional environment at about $8.5 \mathrm{~m}$ depth (Schwamborn et al., 2012) likely forced the microbial communities to react, consistent with the development of unique and diverse microbial communities in both parts of the section. Sediments deposited under subaquatic conditions $(20-8.5 \mathrm{~m})$ are generally characterised by low concentrations of branched and isoprenoid GDGTs, indicating a relatively small number of microorganisms in these sediments (Figure 2b, c). The amounts of branched and isoprenoid GDGTs reported for sediments in the centre of Lake El'gygytgyn during previous glacial-interglacial cycles (MIS 13 to 9) were considerably higher, with values from 200 to $3400 \mathrm{ng}$ branched GDGTs and 20 to $870 \mathrm{ng}$ isoprenoid GDGTs $\mathrm{g}^{-1}$ sediment $\mathrm{dw}$ (J. Bischoff et al., manuscript in preparation).

The low numbers of microbial lipid markers in the subaquatic interval reflect a low abundance of microorganisms during or after the time of deposition. A plausible explanation is likely the low TOC content in these sediments (TOC below the detection limit; Figure 2a), resulting in a lower substrate availability for the indigenous microbial communities. In contrast, the sediments from the centre of the lake (ICDP site 5011-1, Figure 1b) contain higher TOC contents ranging from 0.1 to $3.3 \mathrm{wt}$ per cent and microbial abundances likely driven by an intra-lake production of algal biomass (J. Bischoff et al., manuscript in preparation). The low organic matter deposition might be explained by sedimentary analyses of the subaquatic interval; predominantly coarse-grained materials such as gravel and sand are found there. High-energy conditions typical of a progradational fan delta, with alluvial transport and 

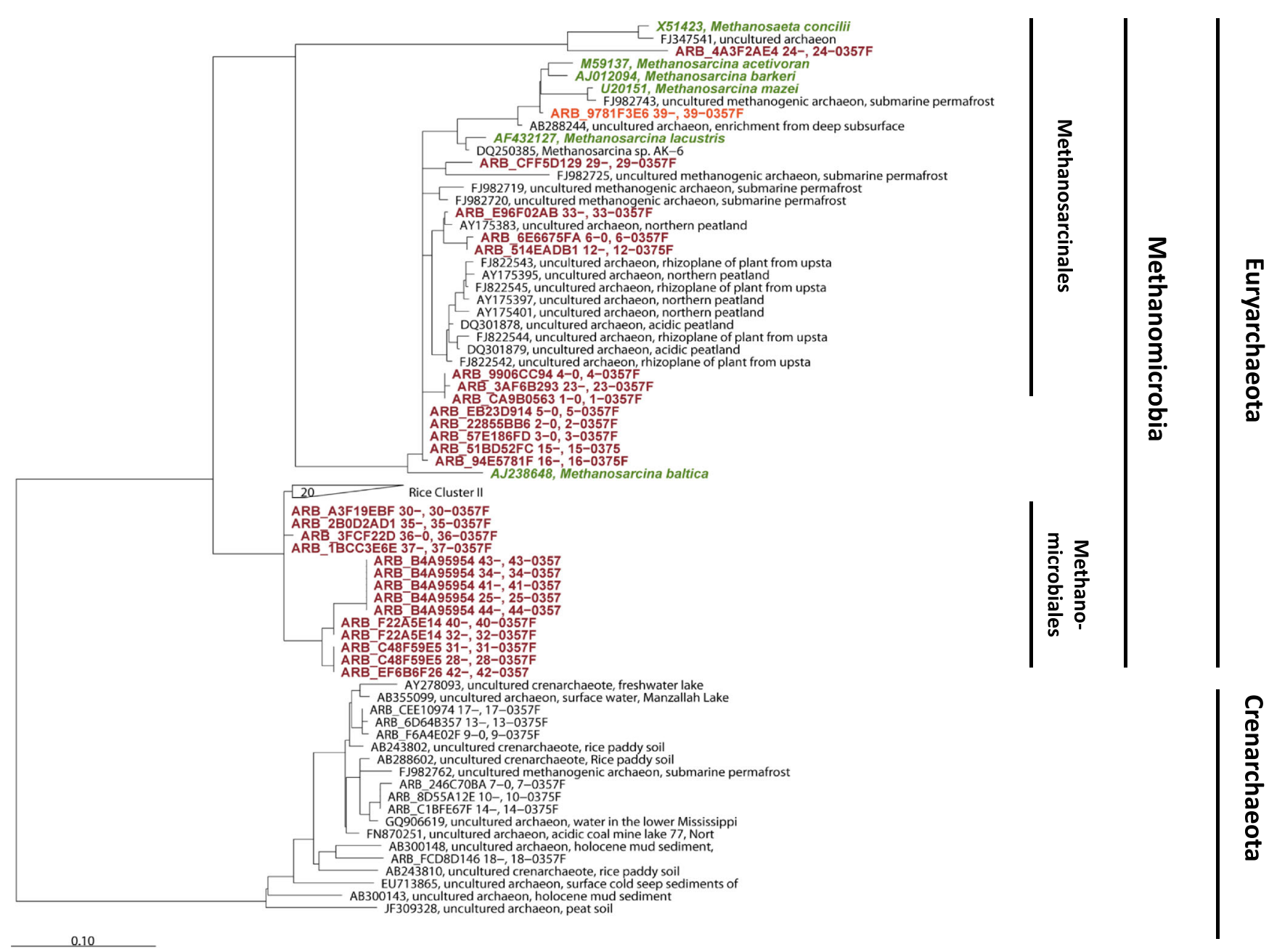

Figure 4 Phylogenetic tree showing the relation of $16 \mathrm{~S}$ ribosomal ribonucleic acid gene sequences of methanogenic Archaea obtained from terrestrial permafrost deposits of Lake El'gygytgyn. The tree represents a maximum parsimony tree based on sequence data provided by the Silva database (see Phylogenetic Analysis). Sequences of methanogenic Archaea that were obtained in the scope of this work are coloured red. Pure cultures that were related closest to our sequences are coloured green.

slope processes, are, therefore, thought to have prevented the deposition of fine-grained material (clay, organic particles and pollen) (Schwamborn et al., 2012). This scenario would lead to the transport and deposition of finer material, including organic particles, further downslope into the deeper part of the lake. The low availability of organic carbon during the subaquatic interval at the drilling site could explain the low abundance of microbial communities and, therefore, the lack of lipid biomarkers at this site. However, because of the increased transport processes, the removal of DNA or lipid biomarkers cannot be excluded.

Despite the low abundance of isoprenoid microbial lipid markers, the relative proportion of isoprenoid GDGTs relative to archaeol reveals a hint about the archaeal community in the subaquatic interval (Figure 3). Generally, the subaquatic deposits contain a high proportion of GDGT- 0 and crenarchaeol. Archaeol is usually absent. GDGT-0 is a characteristic biomarker for methanogenic Archaea (De Rosa and Gambacorta,
1988), indicating that the limited archaeal community found in the subaquatic interval of the analysed core contained a significant proportion of methanogenic Archaea. Methanogenic Archaea were found in the top section of this core, in the sediments from the centre of Lake El'gygytgyn (J. Bischoff et al., manuscript in preparation) and in other cold lakes, such as Lake Fryxell (Karr et al., 2006) and Ace Lake (Coolen et al., 2004) in Antarctica. Furthermore, methanogenic Archaea are described to be able to withstand harsh environmental conditions such as low temperatures and starvation (Morozova and Wagner, 2007; Wagner et al., 2013) and are, therefore, not unexpected for this environment. Despite the occurrence of methanogenic biomarkers, microbiological analyses of methanogenic fingerprints for this interval were not successful and, therefore, a phylogenetic classification was not possible. A further indicative marker for the subaquatic conditions during the time when the lower part of the core was deposited is the high relative proportion of 
crenarchaeol. Crenarchaeol was described as a characteristic biomarker for Crenarchaeota Group I in marine environments (Damste et al., 2002), but was later re-defined as an indicator for Thaumarchaeota (Schouten et al., 2013). Crenarchaeol was more recently found in high proportions, $\leq 49$ per cent of all analysed GDGTs in the cold, lacustrine sediments in northern Scandinavia (Blaga et al., 2009), the Swiss Alps (Bechtel et al., 2010) and in Siberian arctic terrestrial environments (Bischoff et al., 2013). Further research is necessary to better constrain the source organisms of this ubiquitous biomarker.

\section{Microbial Communities in Subaerial Deposits}

The decrease of the Lake El'gygytgyn water level during the late Allerød exposed the lake margin site on the western shore of the lake to subaerial conditions; similar surface conditions are present today in a channel environment on the delta plain (Schwamborn et al., 2012). Although there is only a slow increase in the abundance of bacterial and archaeal GDGTs that do not occur lower than the $7.5 \mathrm{~m}$ depth (Figure 2b, c), the environmental change is better reflected in the change in the relative proportion of isoprenoid GDGTs (Figure 3) versus archaeol, which shows a clear distinction between subaquatic lake and subaerial terrestrial sediments. In contrast to the subaquatic interval, archaeol becomes the most prominent isoprenoid compound in the subaerial succession. Archaeol is also considered to be a characteristic lipid marker for methanogenic Archaea (De Rosa and Gambacorta, 1988). However, the relative proportion of GDGT-0 and archaeol differs throughout different methanogenic genera (Koga and Morii, 2006). Therefore, the shift from GDGT-0 to archaeol at the transition from subaquatic to subaerial conditions might reveal a change in the composition of the methanogenic community in response to the changing lake level. As reported earlier, gene analyses were only possible in the uppermost subaerial layers which contained a high abundance of Methanosarcinaceae and Methanosaetaceae (Figure 4); both genera are known to produce archaeol. In contrast, GDGT-0 is only a minor component in Methanosarcinaceae and Methanosaetaceae and occurs only in some species within Methanococcaceae (Koga et al., 1998). Thus, the gene analysis data coincide with the relatively high proportion of archaeol versus GDGT-0 in the subaerial section. Since DGGE fingerprint analyses were not successful below $8 \mathrm{~m}$ depth, no further information on the archaeal community in the subaquatic section could be obtained.

Methanosarcina-related sequences have previously been found in permafrost-affected soils and sediments (Bischoff et al., 2013; Ganzert et al., 2007; Koch et al., 2009) in temporarily or permanently cold environments, and new Methanosarcina strains have been isolated (Simankova et al., 2001; Wagner et al., 2013) from Russian Arctic soils. In addition to the relatives of Methanosarcina, a number of sequences isolated from the shore of Lake El'gygytgyn were affiliated to Rice Cluster II belonging to the order
Methanomicrobiales (Figure 4). The analyses of the microbial communities within the centre of Lake El'gygytgyn (J. Bischoff et al., manuscript in preparation) show that affiliates of Methanosarcina and Methanomicrobiales (Rice Cluster II) are both abundant in glacial and interglacial sediments in the central lake, which illustrates that transport processes from the lake shore to the lake centre might take place constantly across the climate cycles.

\section{Microbial Succession in the Younger Dryas and Holocene Sequence}

Throughout the Younger Dryas until the onset of the Holocene, the bacterial and archaeal biomarker data indicate again a decrease in the microbial community, which might be related to the temperature decrease during this interval as was observed at another terrestrial site (Bischoff et al., 2013). The microbial communities in the Holocene sedimentary strata clearly differ from those in the underlying deposits (Figure $2 \mathrm{a}-\mathrm{g}$ ). The uppermost layers (1.8-0.0 m core depth) contain an active layer (Schwamborn et al., 2012) and are characterised by an overall increase in TOC and microbial abundance (Figure 2). In addition to the increased bacterial and archaeal lipid markers, high bacterial and archaeal SSU rRNA gene copy numbers together with the diverse fingerprint pattern of methanogenic Archaea (Figure 2) indicate the establishment of an abundant microbial community with a significant proportion of methanogens during the Holocene. The high number of gene copies and different DNA bands in the DGGE analyses suggest an abundance of living microorganisms. This was supported by a significant increase in the phospholipid life markers (PLFAs) (Figure 2e) found in the near-surface layers. The data suggest that with the beginning of the Holocene warming soil formation processes started, leading to the incorporation of organic matter as was previously shown for the uppermost permafrost layers (Schwamborn et al., 2012). Plant remains that were ${ }^{14} \mathrm{C}$-dated show ages that are too old to match the pollen ages (Andreev et al., 2012), suggesting the presence of reworked material in the deposits. Soils in polar regions, especially in mountain ranges, are often poorly developed and contain low carbon and nitrogen values because the cold temperatures restrict the physical, chemical and biological processes that are involved in soil formation (Chapin et al., 1994). Nevertheless, microorganisms contribute to the primary processes of pedogenesis (Schuette et al., 2009) with their ability to support chemical and mechanical bedrock degradation (Frey et al., 2010) in cold environments. It is suggested that similar processes operated in the investigated core during the Holocene, supporting the development of abundant microbial communities.

Furthermore, the data suggest that the establishment of a significant archaeal community, presumably including methanogenic activity, started during the late Allerød when the deposits were exposed to subaerial conditions. After a small interruption during the cold Younger Dryas, the community became abundant during the Holocene probably as a 
consequence of pedogenesis. Thus, past methane formation at the investigated lake shore site is mainly indicated during the subaerial interval, especially during the Holocene, where methanogens could still be identified in the permanently frozen successions. During the subaquatic interval, high-energy conditions together with very low TOC contents might have prevented an abundant microbial community with its intensive methane generation from being established.

\section{CONCLUSION}

This paper presents new data on the distribution of bacterial and archaeal communities in frozen deposits from the western shore of Lake El'gygytgyn in the Far East Russian Arctic. During the sedimentation history, the site changed from a lake environment into a fully frozen slope after the lake level receded during the late Allerød. The lake-level retreat caused changes in the microbial community and this is particularly apparent in the relative composition of archaeal lipid biomarkers. After the site was exposed to subaerial conditions, the bacterial and archaeal communities increased and soil formation processes slowly started, especially during the Holocene when microorganisms might be involved in and stimulated by the pedogenetic processes. Methane formation in the past is indicated for the subaerial interval, especially during the Holocene when the presence of methanogens has been clearly established. This is of central importance when considering the prediction that future global warming will be most pronounced in the Arctic and will, in particular, affect the uppermost layers of permafrost.

\section{ACKNOWLEDGEMENTS}

This study was supported by the Deutsche Forschungsgemeinschaft in the framework of the priority programme International Continental Scientific Drilling Program (grants to DW (WA 1554/10) and KM (MA 2470/4)). The Lake El'gygytgyn sediments were recovered in the scope of the ICDP project Scientific Drilling at El'gygytgyn Crater Lake in 2008. Funding for this research was provided by the ICDP, the US National Science Foundation, the German Federal Ministry of Education and Research, the Alfred Wegener Institute, Helmholtz Centre for Polar and Marine Research, the Helmholtz Centre Potsdam GFZ German Research Centre for Geosciences, the Russian Academy of Sciences Far East Branch, the Russian Foundation for Basic Research and the Austrian Federal Ministry of Science and Research. We greatly appreciate the technical assistance and help of Anke Kaminski, Cornelia Karger, Janine Görsch, Patrick Häcker and Frederik Büks (all GFZ), and of Ryan Pereira for his help with the manuscript. Finally, we thank Candace O'Connor for language services and two anonymous reviewers for constructive comments.

\section{REFERENCES}

Andreev AA, Morozova E, Fedorov G, Schirrmeister L, Bobrov AA, Kienast F, Schwamborn G. 2012. Vegetation history of central Chukotka deduced from permafrost paleoenvironmental records of the El'gygytgyn Impact Crater. Climate of the Past 8: 1287-1300.

Baker GC, Smith JJ, Cowan DA. 2003. Review and re-analysis of domain-specific $16 \mathrm{~S}$ primers. Journal of Microbiological Methods 55: 541-555.

Bechtel A, Smittenberg RH, Bernasconi SM, Schubert CJ. 2010. Distribution of branched and isoprenoid tetraether lipids in an oligotrophic and a eutrophic Swiss lake: Insights into sources and GDGT-based proxies. Organic Geochemistry 41: 822-832.

Bischoff J, Mangelsdorf K, Gattinger A, Schloter M, Kurchatova AN, Herzschuh U, Wagner D. 2013. Response of methanogenic archaea to Late Pleistocene and Holocene climate changes in the Siberian Arctic. Global Biogeochemical Cycles 27: 305-317.

Blaga CI, Reichart G-J, Heiri O, Damste JSS. 2009. Tetraether membrane lipid distributions in water-column particulate matter and sediments: a study of 47 European lakes along a north-south transect. Journal of Paleolimnology 41: 523-540.

Bligh EG, Dyer WJ. 1959. A rapid method of total lipid extraction and purification. Canadian Journal of Biochemistry and Physiology 37: 911-917.

Chapin FS, Walker LR, Fastie CL, Sharman LC. 1994. Mechanisms of Primary Succession Following Deglaciation at Glacier Bay, Alaska. Ecological Monographs 64: 149.

Coolen MJL, Hopmans EC, Rijpstra WIC, Muyzer G, Schouten S, Volkman JK, Sinninghe Damsté JS. 2004. Evolution of the methane cycle in Ace Lake (Antarctica) during the Holocene: response of methanogens and methanotrophs to environmental change. Organic Geochemistry 35: 1151-1167.

Damste JSS, Schouten S, Hopmans EC, van Duin ACT, Geenevasen JAJ. 2002. Crenarchaeol: the characteristic core glycerol dibiphytanyl glycerol tetraether membrane lipid of cosmopolitan pelagic crenarchaeota. Journal of Lipid Research 43: 1641-1651.

De Rosa M, Gambacorta A. 1988. The lipids of archaebacteria. Progress in Lipid Research 27: 153-175.

DeLong EF. 1992. Archaea in coastal marine environments. Proceedings of the National Academy of Sciences 89: 5685-5689.
Frey B, Rieder SR, Brunner I, Ploetze M, Koetzsch S, Lapanje A, Brandl H, Furrer G. 2010. Weathering-Associated Bacteria from the Damma Glacier Forefield: Physiological Capabilities and Impact on Granite Dissolution. Applied and Environmental Microbiology 76: 4788-4796.

Ganzert L, Jurgens G, Münster U, Wagner D. 2007. Methanogenic communities in permafrost-affected soils of the Laptev Sea coast, Siberian Arctic, characterized by $16 \mathrm{~S}$ rRNA gene fingerprints. FEMS Microbiology Ecology 59: 476-488.

Glushkova OY, Smirnov VN. 2007. Pliocene to Holocene geo- morphic evolution and paleogeography of the Elgygytgyn Lake region, NE Russia. Journal of Paleolimnology 37: $37-47$.

Hershberger KL, Barns SM, Reysenbach A-L, Dawson SC, Pace NR. 1996. Wide diversity of Crenarchaeota. Nature 384: 420.

Juschus O, Pavlov M, Schwamborn G, Preusser F, Fedorov G, Melles M. 2011. Late Quaternary lake-level changes of Lake El'gygytgyn, NE Siberia. Quaternary Research 76: 441-451.

Karr EA, Ng JM, Belchik SM, Sattley WM, Madigan MT, Achenbach LA. 2006. Biodiversity of methanogenic and other Archaea in the permanently frozen Lake Fryxell, 
Antarctica. Applied and Environmental Microbiology 72: 1663-1666.

Koch K, Knoblauch C, Wagner D. 2009. Methanogenic community composition and anaerobic carbon turnover in submarine permafrost sediments of the Siberian Laptev Sea. Environmental Microbiology 11: 657-668.

Koga Y, Morii H. 2006. Special methods for the analysis of ether lipid structure and metabolism in archaea. Analytical Biochemistry 348: 1-14.

Koga Y, Morii H, Akagawa-Matsushita M, Ohga I. 1998. Correlation of polar lipid composition with 16S rRNA phylogeny in methanogens. Further analysis of lipid component parts. Bioscience, Biotechnology, and Biochemistry 62: 230-236.

Layer PW. 2000. Argon-40/argon-39 age of the El'gygytgyn impact event, Chukotka, Russia. Meteoritics \& Planetary Science 35: 591-599.

Ludwig W, Strunk O, Westram R, Richter L, Meier H, Yadhukumar Buchner A, Lai T, Steppi S, Jobb G, Förster W, Brettske I, Gerber S, Ginhart AW, Gross O, Grumann S, Hermann S, Jost R, König A, Liss T, Lüßmann R, May M, Nonhoff B, Reichel B, Strehlow R, Stamatakis A, Stuckmann N, Vilbig A, Lenke M, Ludwig T, Bode A, Schleifer KH. 2004. ARB: a software environment for sequence data. Nucleic Acids Research 32: 1363-1371.

Melles M, Brigham-Grette J, Minyuk PS, Koeberl C, Andreev AA, Cook TL 2011. The Lake El'gygytgyn Scientific Drilling Project - Conquering Arctic Challenges through Continental Drilling. Scientific Drilling 11: 29-40.

Melles M, Brigham-Grette J, Minyuk PS, Nowaczyk NR, Wennrich V, DeConto RM, Anderson PM, Andreev AA, Coletti A, Cook TL, Haltia-Hovi E, Kukkonen M, Lozhkin AV, Rosen P, Tarasov P, Vogel H, Wagner B. 2012. 2.8 Million Years of Arctic Climate Change from Lake El'gygytgyn, NE Russia. Science 337: 315-320.

Morozova D, Wagner D. 2007. Stress response of methanogenic archaea from Siberian permafrost compared with methanogens from nonpermafrost habitats. FEMS Microbiology Ecology 61: 16-25.
Mottaghy D, Schwamborn G, Rath V. 2013. Past climate changes and permafrost depth at the Lake El'gygytgyn site: implications from data and thermal modeling. Climate of the Past 9: 119-133.

Müller K-D, Husmann H, Nalik HP. 1990. A New and Rapid Method for the Assay of Bacterial Fatty Acids Using High Resolution Capillary Gas Chromatography and Trimethylsulfonium Hydroxide. Zentralblatt für Bakteriologie 274: 174-182.

Nadkarni MA, Martin FE, Jacques NA, Hunter N. 2002. Determination of bacterial load by real-time PCR using a broad-range (universal) probe and primers set. Microbiology-SGM 148: 257-266.

Nolan M. 2012. Analysis of local AWS and NCEP/NCAR reanalysis data at Lake El'gygtytgyn, and its implications for maintaining multi-year lake-ice covers. Climate of the Past Discussions 8: 1443-1483. DOI: 10.5194/cpd-8-1443-2012

Nolan M, Brigham-Grette J. 2007. Basic hydrology, limnology, and meteorology of modern Lake El'gygytgyn, Siberia. Journal of Paleolimnology 37: 17-35.

Pancost RD, McClymont EL, Bingham EM, Roberts Z, Charman DJ, Hornibrook ERC, Blundell A, Chambers FM, Lim KLH, Evershed RP. 2011. Archaeol as a methanogen biomarker in ombrotrophic bogs. Organic Geochemistry 42: 1279-1287.

Pease TK, Van Vleet ES, Barre JS, Dickins HD. 1998. Simulated degradation of glyceryl ethers by hydrous and flash pyrolysis. Organic Geochemistry 29: 979-988.

Pruesse E, Quast C, Knittel K, Fuchs BM, Ludwig W, Peplies J, Glöckner FO. 2007. SILVA: a comprehensive online resource for quality checked and aligned ribosomal RNA sequence data compatible with ARB. Nucleic Acids Research 35: 7188-7196.

Schouten S, Huguet C, Hopmans EC, Kienhuis MV, Damste JS. 2007. Analytical methodology for TEX86 paleothermometry by high-performance liquid chromatography/ atmospheric pressure chemical ionizationmass spectrometry. Analytical Chemistry 79: 2940-2944.

Schouten S, Hopmans EC, Sinninghe Damsté JS. 2013. The organic geochemistry of glycerol dialkyl glycerol tetraether lipids: A review. Organic Geochemistry 54: 19-61.
Schuette UME, Abdo Z, Bent SJ, Williams CJ, Schneider GM, Solheim B, Forney LJ. 2009. Bacterial succession in a glacier foreland of the High Arctic. ISME Journal 3: 1258-1268.

Schwamborn G, Fedorov G, Ostanin N, Schirrmeister L, Andreev A, the El'gygytgyn Scientific P 2012. Depositional dynamics in the El'gygytgyn Crater margin: implications for the 3.6 Ma old sediment archive. Climate of the Past 8: 1897-1911.

Simankova MV, Parshina SN, Tourova TP, Kolganova TV, Zehnder AJB, Nozhevnikova AN. 2001. Methanosarcina lacustris sp nov., a new psychrotolerant methanogenic archaeon from anoxic lake sediments. Systematic and Applied Microbiology 24: 362-367.

Vetter A, Vieth-Hillebrand A, Schettler G, Seibt A, Wolfgramm M, Mangelsdorf K. 2011. Biogeochemical monitoring of a shallow geothermally used aquifer in the North German Basin. Zeitschrift für Geologische Wissenschaften 39(3/4): 241-260.

Wagner D, Schirmack J, Ganzert L, Morozova D, Mangelsdorf K. 2013. Methanosarcina soligelidi sp. nov., a desiccation and freezethaw resistant methanogenic archaeon isolated from a Siberian permafrost-affected soil. International Journal of Systematic and Evolutionary Microbiology 63: 2986-2991.

Watanabe T, Asakawa S, Nakamura A, Nagaoka K, Kimura M. 2004. DGGE method for analyzing $16 \mathrm{~S}$ rDNA of methanogenic archaeal community in paddy field soil. FEMS Microbiology Letters 232: 153-163.

Weijers JWH, Schouten S, Hopmans EC, Geenevasen JAJ, David ORP, Coleman JM, Pancost RD, Damste JSS. 2006. Membrane lipids of mesophilic anaerobic bacteria thriving in peats have typical archaeal traits. Environmental Microbiology 8: $648-657$.

White DC, Davis WM, Nickels JS, King JD, Bobbie RJ. 1979. Determination of the sedimentary microbial biomass by extractible lipid phosphate. Oecologia 40: 51-62.

Zink K-G, Mangelsdorf K. 2004. Efficient and rapid method for extraction of intact phospholipids from sediments combined with molecular structure elucidation using LC-ESI-MS-MS analysis. Analytical and Bioanalytical Chemistry 380: 798-812. 